\title{
Analysis of Different Factors of Occupational Stress and Associated Health Problems in West Bengal
}

\author{
Sanjib Kumar Gupta \\ Assistant Professor of Statistics, Sarsuna College, Kolkata, West Bengal, India \\ E-mail: gsanjib.stat@gmail.com
}

\begin{abstract}
In this modern era, stress becomes a major and relevant problem almost all over the world. Due to increasing trend of stress in every aspect of human life, the 21st century may be looked upon as a century of the stress. Even as days progress, the participation of women in different occupational sector is significantly increasing along with male. Recently, stress is also rising due to globalization and global financial crisis. Occupational stress mainly arises due to unsuitable environment, excessive workload, long time to work, multidimensional work, less salary, non-permanent job, lack of task control, poor relation with higher authority, etc. the main objective of this paper is to find out various factors of occupational stress in West Bengal. In West Bengal, there are various government and non-government sectors with organized and unorganized divisions. Primary data, related to occupational stress, have been collected from the districts of West Bengal. A five-points Likert scale has been used to estimate occupational stress. The average stress score has been determined for the people of rural and urban areas and government and non-government sectors. Chi-square test is applied to test hypotheses related to occupational stress. Factor analysis is implemented to identify the key factors which may directly affect on occupational stress. Logistic regression analysis is utilized to test the significant impacts of few vital socio-economic factors on occupational stress. Mental and physical health issues among the respondents for occupational stress have been identified. The result shows that there is a moderate occupational stress on an average among the employees of West Bengal. However, there is a significant difference in the stress level among rural and urban people as well as government and non-government workers. The result also illustrates that job type, age, occupation, environment of workplace, spending hours at office place, help from colleagues, promotion system, pressure to perform have highly significant impact on occupational stress.
\end{abstract}

Keywords: Occupational Stress, Likert Scale, Factor Analysis, Logistic Regression

\section{INTRODUCTION}

Stress comes from the Latin word "strict us" that interprets into taut, which means stiffly strung (Olivier \& Venter, 2003). Whenever individuals feel pressures then they are said to be stressed. The situations that make a person becomes stress are known as stressors. Stress connected with job or occupation is known as occupational stress. It arises once individuals have some responsibilities and demands involving work with that they cannot cope for various reasons. It can negatively influence the work potency, performance, and service quality. In usually, individuals spend most of the time at his/her occupational
Place and hence the stress arise from there. It mainly happens due to inappropriate surroundings, excessive workload, very long time to work, multidimensional work, less remuneration, non-permanent job, lack of task management, poor relation with higher authority, lack of training, etc. Additionally, some external effects too impact on work. Sometimes there might frustration to remain aloof from home for the job, not interacting with the family members and friends, unsuitable weather, not spending enough time with family members, illness of close one, monetary crisis, unable to fulfil basic dreams. Generally, there are three types of occupation. Fisher (1933) introduced the concept of primary, secondary, and tertiary occupations. In all these sectors the stress is not alike. In each sector the individuals engaged in work are seldom face various types of problem and hence it badly affects the economy of a nation. Occupational stress also causes various health problems. In the presence of stress individuals may break down and it comes out in the form of irritation, confusion, anger etc. It badly distracts on the people surrounding him or her as well.

West Bengal, a state of India, is selected for this study purpose. In West Bengal there are almost 100 million of people. According to 2011 census there are 909 towns and 40,203 villages in West Bengal (Census Report, 2011). It extends from $21^{\circ} 25^{\prime} \mathrm{N}$ to $26^{\circ} 50^{\prime} \mathrm{N}$ latitudes and $86^{\circ} 30^{\prime} \mathrm{E}$ to 89 58 'E longitudes and it embraces an area of about 88,968 $\mathrm{km}^{2}$. Total population of West Bengal as per 2011 census is $91,276,115$ of which male and female are 46,809,027 and $44,467,088$ respectively. This contributes to $7.55 \%$ of the country's total population. The gender ratio is 947 females per 1000 males. Almost $68.11 \%$ of population lives in rural areas and $31.89 \%$ of population urban areas. In this state there are 23 districts. Several organized and unorganized sectors of work is running in this state. Even as days progress, the participation of women in occupational sectors is significantly increasing. In the big cities, like Kolkata, there are plenty of IT (Information technology) industries along with other flourished industries.

However, in the rural area most of the people are depending on agriculture. Lesser people are involved in government jobs, IT jobs and other office jobs. Thus, the working environment differs among the people of rural and urban areas. Also, the pressure of the IT employees is not same as that are among the other professions, mainly government 
jobs. The timing on workplace differs from one profession to another. So, I want to analyze how these issues impact on occupational stress. In this present paper one of the objectives is also to find out the significant causes or stressors of occupational stress. This paper has been organized as follows. In Section II a literature review related to occupational stress has been discussed. Section III reveals the objective of this study. Section IV consists of the data collection method and methodology applied for the work. Results and discussion are given in Section V. Section VI concludes the work and discusses some ways out of its possible prevention from the occupational stress.

\section{REVIEW OF LITERATURE}

This literature review consists of three parts. The first part discusses the international research work on occupational stress. The same work done by Indian researchers except West Bengal state is mentioned in the second part. Third part covers previous research works related to occupational stress in West Bengal. Weiss (1983) discussed the effects of work stress and social support on information system managers. According to Lazarus \& Folkman (1984), stress occurs when the demands that are being placed upon a person tax or exceed available resources as appraised by the individual involved. Landsbergis (1988) studied occupational stress among health care workers by using job demands-control model. Nelson \& Sutton (1990) considered the stress of newcomers to the occupational field.

They carried out a study to show the relationship between chronic work stressors, coping techniques, distress symptoms and work performance among organizational newcomers. Cooper and Marshal (1976) suggested that occupational stress includes the environmental factors associated with a particular job. Orpen (1991) mentioned that occupational environment plays a major factor of stress. Wastell \& Newman (1993) identified causes of stress at workplace.

Sharply (1996) observed that people of age group between 31 and 40 are more stressed than other age groups among the workers. Emsley (2003) highlighted managers' jobrelated tension and the deterioration of the performance. Manshor et al. (2003) investigated the occupational stressors among Malaysian managers working in multinational companies. Berg et al. (2006) said that the prevalence of subjective health complaints was relatively high among the Norwegian police and was mainly associated to job pressure and lack of support. Angelo and Chambel (2013) established a relationship between work characteristics and employee burnout. Manton (1990) discussed the connection of occupational stress with family.

Barnett \& Brennan (1995) studied the relationship between job experiences and psychological distress. Dependence between work stress and health has been studied by Wilkins \& Beaudet (1998). Lait \& Wallace (2002) discussed the significance contribution of certain working conditions that affect stress in a workplace. Michie (2002) pointed out that liking or disliking of the surrounding people at the workplace is a major source of occupational stress. Harshna (2018) reviewed literature on the topic of work-related stress. Susiarty et al. (2019) reported that stress among the nurse is related with workload, working conditions, and relationship at workplace. Plaisier et al. (2007) observed that poor working condition creates a lot of stress. Stimulus (2006) revealed significant difference in stress among the staff of private sector and public sector. Cohen \& Single (2001) listed the symptoms of stress. They categorized the symptoms into five major groups- emotional, physical, behavioral, mental and heath.

If literature from India is considered, then it has been noticed that Upadhyay \& Singh (1999) worked with teachers and executives, and they found the executives as well as the teachers experienced a moderate level of stress and the executives experienced more stress than the teachers. Jagdish \& Shrivastava (1989) established the relationship between perceived occupational stress stemming from various job dimensions and mental health of the first level supervisors. Shah (2003) examined role stress among employees in banking industry. Sudhashree et al. (2005) concentrated on occupational stress among call center employees. Sharma et al. (2006) highlighted computer related health problems among information technology professionals in Delhi.

Kulkarni (2006) pointed out that rapid change of the modern working life, associated with the increasing demands of learning new skills and hectic jobs, increases stress level among the employees. Based on their survey, Bhatia et al. (2010) highlighted that $87.4 \%$ of nurses experienced occupational stress in Delhi. Kavitah (2012) discussed the stress among women employees at IT sector in Chennai and Coimbatore. Jayashree (2010) reveled that stress increases absenteeism, frequency of drinking and smoking. Nagra \& Arora (2013) observed that teacher`s educators experience moderate level of occupational stress.

Rathore \& Ahuja (2015) highlighted the occupational stress among the IT professionals. Sreelekha \& Rajeswari (2016) addressed the stress among nurses in a tertiary care hospital. Parray et al. (2016) theoretically examined stress among the teachers. Hasan (2014) compared the stress between private and government school teachers. Sing \& Katoch (2017) discussed the occupational stress among the higher secondary teachers. Kakada \& Deshpande (2018) studied the perception of 120 faculty members in private engineering college in Nagpur towards the work environment and the impact on job stress.

Now, this part deals with the literature of occupational stress that connected with West Bengal. Deb et al. (2008) found that near about $80 \%$ of the traffic constable of West Bengal were stressed. They also identified the causes of the stress. Bandyopadhyay \& Sen (2014) conducted a field survey on female laborers working in several manual brick 
manufacturing units of West Bengal and found that the workers are facing working stress. Bhuin (2017) tested hypotheses related to stress among the teachers and administrators of private management schools of West Bengal. Purakait (2016) studied the impact of occupational stress among the banking workers of West Bengal. Mondal \& Mistry (2018) examined the relationship between teacher's stress with teaching satisfaction of elementary school teachers in West Bengal.

\section{OBJECTIVES OF THE STUDY AND RESEARCH QUESTION}

The present study focuses on major causes of occupational stress among the people of West Bengal with the help of statistical analysis. Various professions are selected to identify different types of stress. A suitable regression model between the stress and the vital socio-economic factors is fitted to mark the significant effects of the factors on occupational stress. The purpose of the study is also to find out its effects on the health of the people of the West Bengal. Factor analysis is implemented to identify ten major causes of the occupational stress. The following null hypotheses are also tested.

1. There is no significant relationship between occupational stress and the type of occupation.

2. There is no significant relationship between occupational stress and the remuneration for the work.

3. There is no significant relationship between occupational stress and the year of experience.

4. There is no significant relationship between occupational stress and the availability of the transport system.

5. There is no significant relationship between occupational stress and the environment of the working place.

6. There is no significant difference in occupational stress in relation to age.

7. There is no significant difference in occupational stress in relation to gender.

8. There is no significant difference in occupational stress in relation to marital status.

9. There is no significant relationship between occupational stress and health.

10. Employees of IT sectors experience the same stress as non-IT sector employees' experience.

11. Employees of government sectors experience the same stress as private sector employees' experience.

12. There is no significant difference in occupational stress between the people employed on the permanent and Ad-hoc basis.

This present paper is also carried out a comparative study between rural and urban area based on the outcomes. To compare this testing hypothesis will be:

There is no significant difference between the rural and urban people in respect of occupational stress. Another objective of this paper is to identify different health related problems associated with occupational stress.

\section{RESEARCH DESIGN AND METHODS}

A questionnaire has been prepared to collect the data. Relevant questions related to occupational stress are pointed there. There are basically three parts of the questionnaire. In the first part the information related basic information like gender, caste, area, district, area of job, educational qualification, marital status, occupation, income, transport, mode of work, duty hours, working experiment etc are collected. There are 20 questions in this first part.

Most questions have multiple choices. Professions like doctor, teacher, engineer, lawyer, banker, clerk, nurse, ITprofessional, driver, businessman, carpenter, potter, reporter, singer, actor/actress are considered. If the occupation of a respondent is other than these professions, then one is considered as 'other' category.

The second part of the questionnaire measures the stress. Maximum questions are expressed on a five-points Likert scale: (i) not at all (ii) a little (iii) somewhat (iv) much (v) very much. After collection, the data have rearranged in such a way that larger is the value more is the stress. Not at all, a little, somewhat, much, and very many responses are allotted 1, 2, 3, 4 and 5 numbers respectively.

There are 50 questions in this second part. Among these 40 questions measure the stress through average score of Likert scale. Remaining questions are related to infrastructure of the workplace. The overall average score has been calculated. The same for rural and urban people are also determined separately. Health and psychological issues and the way of relief from stress are considered in the third part. These are all multiple-choices questions.

Interview method and mail-questionnaire methods are adopted to collect the relevant data. The present study tried to cover maximum districts of West Bengal. For this purpose, I have visited the districts of West Bengal and collected information from both rural and urban areas. To gather more information questionnaires are sent through mail as well. 5642 questionnaires are supplied to the people (including mail). Among these, 4766 individuals were responded. Two stage sampling schemes with combination of stratified sampling and systematic sampling is adopted to collect data. All the data are arranged on the excel sheets.

Various statistical tools and techniques are applied for the analysis purpose. The average Likert score is estimated. The value of Cronbach alpha is determined. Logistic regression analysis has been done to assess the impact of selected socio-economic factors with occupational stress. Chi-square test has been performed for testing the above hypotheses mentioned in Section III. Factor analysis will also be done to identify the job-related direct factors that are responsible for occupational stress. 


\section{RESULTS AND DISCUSSION}

Among the collected 4766 questionnaires the representation from the districts is depicted in Table 1.

TABLE I REPRESENTATION OF RESPONDENT DISTRICT WISE

\begin{tabular}{|l|c|}
\hline \multicolumn{1}{|c|}{ District } & Percentage \\
\hline Kolkata & 09 \\
\hline Howrah & 04 \\
\hline North 24 Parganas & 03 \\
\hline South 24 Parganas & 09 \\
\hline Nadia & 03 \\
\hline Purba Bardhaman & 03 \\
\hline Paschim Bardhaman & 03 \\
\hline Hooghly & 04 \\
\hline Birbhum & 17 \\
\hline Darjeeling & 01 \\
\hline Alipurduar & 01 \\
\hline Jalpaiguri & 02 \\
\hline Kalimpong & 01 \\
\hline Cooch Behar & 03 \\
\hline Malda & 07 \\
\hline Uttar Dinajpur & 03 \\
\hline Dakshin Dinajpur & 02 \\
\hline Mursidabad & 06 \\
\hline East Midnapore & 02 \\
\hline West Midnapore & 04 \\
\hline Jhargram & 01 \\
\hline Purulia & 04 \\
\hline Bankura & 08 \\
\hline & \\
\hline & 100 \\
\hline
\end{tabular}

It has been shown that representation of respondent from Birbhum is highest and representation from the districts Darjeling, Kalinpang, Jhargram is lesser. 56\% respondents are from urban and $44 \%$ are of from rural areas. Samples from urban are more preferred than rural because it is expected that working people (except agriculture, daily labor etc) dominantly belong to the urban area.

Findings from Part 1 of the questionnaire:

1. In first question $72 \%$ provides their name but remaining 28\% does not reveal it.

2. Gender distribution: 62\% Male, 37\% Female and 1\% transgender.

3. Caste distribution: $71 \%$ General, $17 \%$ OBC, $8 \%$ SC, $4 \%$ ST.

4. Area of Workplace: 76\% Urban, 24\% Rural.
5. Age (in year) distribution:12\%: 10-20, 31\%: 20-30 34\%: 30-40, 18\%:40-50, 5\%: 50 and more.

6. Educational qualification: $3 \%$ Illiterate, $11 \%$ Primary, 26\% Secondary, 32\% Higher Secondary, 17\% Graduate, $11 \%$ Higher education.

7. Marital Status: $66 \%$ Married, $21 \%$ Single, $8 \%$ Widow, $5 \%$ Divorcee.

8. Occupation: $14 \%$ Teacher, $7 \%$ Clerk, $6 \%$ Businessman, 6\% Engineer, 2\% Doctor, 3\% Nurse, 1\% Carpenter, 16\% IT Professions, 4\% Driver, 1\% Reporter, 1\% Potter, 3\% Lawyer, 1\% Singer, 2\% Actor, $1 \%$ Actress, 3\% Mechanics, 4\% Banker, 1\% Manager (Firm, Hotel etc.), 24\% Other occupation.

9. Income ('000 Rs): $9 \%$ less than 10, 16\%: 10-20, 15\%: 20-30, 33\%: 30-40, 14\%: 40-50, 7\%: 50-60, 4\%: 6070, 2\%: More than 70.

10. Distance $(\mathrm{KM})$ of the workplace from home: $4 \%$ Less than 1, 26\% :1-5, 17\%: 5-10, 32\%: 10-20, 11\%: 20-30, 19\% More than 30.

11. Time (minute) taken to go workplace: $42 \%$ : less than 30 minutes, 36\%: 30-60, 13\%: 60-120, 9\% More than 120.

12. Transport: $17 \%$ Private, $41 \%$ Public, $12 \%$ Office vehicle, $4 \%$ All, $8 \%$ Any two, $8 \%$ None.

13. Mode of employment: $46 \%$ Full time, $22 \%$ Part time, $13 \%$ Contractual $7 \%$ Hourly $12 \%$ Others.

14. Working shift: $31 \%$ Morning, $42 \%$ Noon, $12 \%$ Afternoon, 15\% Night.

15. Working hour per day: $8 \%$ Less than 3, 21\%: 3-5, $43 \%$ : $5-8,28 \%$ : More than 8.

16. Holidays per week: 15\%: 0, 29\%: 1,22\%: 2, 27\%:3,7\%: More than 3.

17. Working experience(year): $8 \%$ Less than $1,22 \%: 1-5$, 30\% :5-10, 30\%: 10-20, 10\% More than 20.

18. Number of dependence family member: $7 \%: 1,21 \%$ : 2, 25\%: 3, 22\%: 4, 17\%: 5, 8\%: More than 5 .

The Likert score of the relevant questions from the second part of the questionnaire are determined in Table 2. Here, higher is the value of mean score higher is the stress.

The average score is found to be 3.4. So there is an average moderate stress among the respondent. Cronbach alpha is obtained as 0.79 . However, the value of this scoreing higher in urban areas (score 3.8) than the rural areas (score 2.9). Hence, the rural inhabitants fell less working pressure than urban inhabitants. Also, the average stress score in govermnment sector is 2.7 and the same in nongovrernment sector is 4.1 .

To find the impact of the socio-economic factors, a regression between occupational stress and the socioeconomic factors is conducted. The stress variable is assigned 1 if the stress score $>2.5$ and 0 otherwise. A logistic regression has been performed here to find the relationship between the independent factors with the occupational stress. Here only p-values along with the estimates are reported corresponding to the coefficients. All the calculations are done in Minitab. 
TABLE II OVERALL AVERAGE SCORE OF DIFFERENT FACTORS RELATED TO OCCUPATIONAL STRESS( 0-2.5- NO STRESS, 2.5-5 STRESS)

\begin{tabular}{|c|c|c|c|c|c|c|c|}
\hline Factor & $\begin{array}{l}\text { Score } \\
\text { ( SD) }\end{array}$ & Factor & $\begin{array}{l}\text { Score } \\
\text { ( SD) }\end{array}$ & Factor & $\begin{array}{l}\text { Score } \\
\text { ( SD) }\end{array}$ & Factor & $\begin{array}{l}\text { Score } \\
\text { ( SD) }\end{array}$ \\
\hline $\begin{array}{l}\text { Job dis- } \\
\text { satisfaction }\end{array}$ & $\begin{array}{c}3.3 \\
(0.9) \\
\end{array}$ & $\begin{array}{c}\text { Behaviour } \\
\text { of colleague }\end{array}$ & $\begin{array}{c}3.6 \\
(1.2) \\
\end{array}$ & $\begin{array}{c}\text { Sufficient } \\
\text { break }\end{array}$ & $\begin{array}{c}4.9 \\
(0.3) \\
\end{array}$ & $\begin{array}{c}\text { Attachment } \\
\text { with job }\end{array}$ & $\begin{array}{c}2.7 \\
(1.2) \\
\end{array}$ \\
\hline Salary & $\begin{array}{c}4.1 \\
(0.6) \\
\end{array}$ & Work speed & $\begin{array}{c}3.3 \\
(0.9) \\
\end{array}$ & Long work & $\begin{array}{c}4.1 \\
(0.7) \\
\end{array}$ & $\begin{array}{c}\text { Laugh at } \\
\text { work-place }\end{array}$ & $\begin{array}{c}3.6 \\
(0.6) \\
\end{array}$ \\
\hline Salary hike & $\begin{array}{c}3.6 \\
(0.7)\end{array}$ & $\begin{array}{c}\text { Independent } \\
\text { Work }\end{array}$ & $\begin{array}{c}4.4 \\
(0.87) \\
\end{array}$ & $\begin{array}{l}\text { Reliable } \\
\text { authority }\end{array}$ & $\begin{array}{c}3.5 \\
(1.2) \\
\end{array}$ & $\begin{array}{c}\text { Promotion } \\
\text { pattern }\end{array}$ & $\begin{array}{c}4.7 \\
(0.9) \\
\end{array}$ \\
\hline Job security & $\begin{array}{l}3.9 \\
(0.9)\end{array}$ & $\begin{array}{c}\text { Different } \\
\text { group work }\end{array}$ & $\begin{array}{c}3.1 \\
(0.6)\end{array}$ & Encouragement & $\begin{array}{c}4.0 \\
(1.4)\end{array}$ & $\begin{array}{c}\text { Self } \\
\text { Confidence }\end{array}$ & $\begin{array}{c}3.0 \\
(1.5)\end{array}$ \\
\hline $\begin{array}{l}\text { Job } \\
\text { comfortable }\end{array}$ & $\begin{array}{c}3.2 \\
(0.5) \\
\end{array}$ & Boring & $\begin{array}{c}2.7 \\
(1.3)\end{array}$ & $\begin{array}{l}\text { Option to } \\
\text { Question } \\
\end{array}$ & $\begin{array}{c}4.6 \\
(0.8) \\
\end{array}$ & Shifting job & $\begin{array}{c}4.1 \\
(0.8) \\
\end{array}$ \\
\hline $\begin{array}{l}\text { Emotional } \\
\text { attachment }\end{array}$ & $\begin{array}{c}4.1 \\
(1.2)\end{array}$ & $\begin{array}{c}\text { Assignment } \\
\text { without } \\
\text { resource }\end{array}$ & $\begin{array}{c}4.1 \\
(0.3)\end{array}$ & $\begin{array}{l}\text { Respect by } \\
\text { other }\end{array}$ & $\begin{array}{l}3.9 \\
(0.7)\end{array}$ & Environment & $\begin{array}{c}3.6 \\
(0.7)\end{array}$ \\
\hline $\begin{array}{l}\text { Spending } \\
\text { time with } \\
\text { family after } \\
\text { job }\end{array}$ & $\begin{array}{l}4.0 \\
(1)\end{array}$ & $\begin{array}{c}\text { Unfair } \\
\text { promotion }\end{array}$ & $\begin{array}{c}3.5 \\
(1.2)\end{array}$ & Anger & $\begin{array}{c}3.3 \\
(1.21)\end{array}$ & Jealousy & $\begin{array}{c}3.9 \\
(1.1)\end{array}$ \\
\hline $\begin{array}{l}\text { Expected } \\
\text { work }\end{array}$ & $\begin{array}{c}3.7 \\
(0.7)\end{array}$ & $\begin{array}{c}\text { Decision } \\
\text { making }\end{array}$ & $\begin{array}{c}4.2 \\
(0.5)\end{array}$ & Bulling & $\begin{array}{c}2.12 \\
(1.23)\end{array}$ & $\begin{array}{c}\text { Think of } \\
\text { changing job }\end{array}$ & $\begin{array}{c}3.3 \\
(0.9)\end{array}$ \\
\hline $\begin{array}{l}\text { Job } \\
\text { knowledge }\end{array}$ & $\begin{array}{c}2.7 \\
(0.9) \\
\end{array}$ & $\begin{array}{l}\text { Supportive } \\
\text { feed back }\end{array}$ & $\begin{array}{c}2.1 \\
(0.8)\end{array}$ & $\begin{array}{c}\text { Relation with } \\
\text { colleague }\end{array}$ & $\begin{array}{c}3.5 \\
(1.05) \\
\end{array}$ & Activity & $\begin{array}{c}3.7 \\
(0.7) \\
\end{array}$ \\
\hline $\begin{array}{l}\text { Deadline } \\
\text { fulfilment }\end{array}$ & $\begin{array}{c}3.7 \\
(1.1)\end{array}$ & $\begin{array}{l}\text { Help from } \\
\text { higher } \\
\text { authority }\end{array}$ & $\begin{array}{c}4.1 \\
(0.9)\end{array}$ & $\begin{array}{l}\text { Work from } \\
\text { home }\end{array}$ & $\begin{array}{c}2.6 \\
(0.9)\end{array}$ & $\begin{array}{c}\text { Job } \\
\text { assurance }\end{array}$ & $\begin{array}{c}4.1 \\
(0.7)\end{array}$ \\
\hline
\end{tabular}

TABLE III LOGISTIC REGRESSION OF OCCUPATIONAL STRESS ON DIFFERENT SOCIO-ECONOMIC FACTORS

\begin{tabular}{|l|c|c|}
\hline Factor & Coefficient & p-value \\
\hline Gender & 1.21 & 0.12 \\
\hline Location & 0.74 & 0.03 \\
\hline Age & -0.62 & 0.01 \\
\hline Income & -0.72 & 0.002 \\
\hline Marital Status & 1.15 & 0.07 \\
\hline Job type & 0.63 & 0.01 \\
\hline $\begin{array}{l}\text { Distance of the } \\
\text { workplace }\end{array}$ & 1.57 & 0.22 \\
\hline Transportation & 0.97 & 0.03 \\
\hline Caste & 0.58 & 0.31 \\
\hline Education & 0.77 & 0.001 \\
\hline $\begin{array}{l}\text { Number of } \\
\text { dependence member }\end{array}$ & 0.83 & 0.04 \\
\hline \begin{tabular}{l} 
Constant \\
\hline
\end{tabular} & 2.33 & 0.13 \\
\hline
\end{tabular}

It has been observed from the table 3 that job type, age, education, income, number of dependent member, transportation, location of the respondent have significant impact on stress at $5 \%$ level of significance. Cluster analysis has been done to measure the similarities.
We have seen that job type, age, education belong to a single group. The identification of key factors associated directly with occupational stress is done based on factor analysis. Table 4 illustrates the result of this analysis. 
TABLE IV STATEMENT LOADINGS OF OCCUPATIONAL STRESS LEVEL, EIGEN VALUES AND \% OF VARIANCES (USING VARIMAX ROTATED PRINCIPAL)

\begin{tabular}{|c|l|c|c|c|}
\hline SL.No. & Factor & Loading & Eigen value & $\begin{array}{c}\text { \% of } \\
\text { variance }\end{array}$ \\
\hline 1 & $\begin{array}{l}\text { I am not satisfied with my } \\
\text { work }\end{array}$ & 0.92 & 15.61 & 17.28 \\
\hline 2 & $\begin{array}{l}\text { I perform tasks that are too } \\
\text { boring }\end{array}$ & 0.83 & 12.32 & 13.84 \\
\hline 3 & $\begin{array}{l}\text { I have little chance/scope in } \\
\text { contributing to decision- } \\
\text { making }\end{array}$ & 0.81 & 10.55 & 10.23 \\
\hline 4 & $\begin{array}{l}\text { The environment of the } \\
\text { workplace is not good }\end{array}$ & 0.78 & 8.21 & 9.83 \\
\hline 5 & $\begin{array}{l}\text { I am unable to take sufficient } \\
\text { breaks }\end{array}$ & 0.87 & 6.39 & 9.21 \\
\hline 6 & $\begin{array}{l}\text { My authority does not } \\
\text { encourage me at work }\end{array}$ & 0.65 & 5.72 & 8.14 \\
\hline 7 & $\begin{array}{l}\text { I do not receive the respect } \\
\text { from the authority }\end{array}$ & 0.72 & 5.41 & 6.63 \\
\hline 8 & $\begin{array}{l}\text { I think of changing the } \\
\text { present occupation }\end{array}$ & 0.70 & 4.99 & 5.10 \\
\hline 9 & My working time is too long & 0.67 & 2.17 & 3.82 \\
\hline 10 & I am not secure about my job & 0.76 & 1.53 & 2.07 \\
\hline
\end{tabular}

A chi-square test is conducted to test the following null hypotheses (For all the following testing we have prepared contingency table).

1. There is no significant relationship between occupational stress and the type of occupation.

(a) $p$-value $=0.003$. There is a significant relationship.

2. There is no significant relationship between occupational stress and the remuneration for the work.

(b) $p$-value $=0.0006$. There is a significant relationship

3. There is no significant relationship between occupational stress and the year of experience.

(c) p-value $=0.07$. There is a slight significant relationship.

4. There is no significant relationship between occupational stress and the availability of the transport

system.

(d) $p$-value $=0.01$. There is a significant relationship.

5. There is no significant relationship between occupational stress and the environment of the working

place.

(e) p-value $=0.007$. There is a significant relationship.

6 . There will be no significant difference in occupational stress in relation to age.

(f) $\mathrm{p}$-value $=0.0003$. There is a strong significant relationship.

7. There is no significant difference in occupational stress in relation to gender.

(g) $p$-value $=0.13$. There is no significant relationship.

8. There is no significant difference in occupational stress in relation to marital status. (h) p-value $=0.09$. There is small significant relationship.

9. There is no significant relationship between occupational stress and health.

(i) $\mathrm{p}$-value $=0.006$, There is a strong significant relationship.

10. Employees of IT sectors experience the same stress as non-IT sector employees' experience.

(j) $p$-value $=0.00001$, There is a very strong significant relationship.

11. Employees of Government sectors experience the same stress as Private sector employees' experience.

(k) $\mathrm{p}$-value $=0.07$. The stress of government sectors is not same as of private sectors.

12. There is no significant difference in occupational stress between the people employed on the Permanent

And Ad-hoc basis.

(l) $\mathrm{p}$-value $=0.006$. There is a very strong significant relationship.

13. There is no significant difference between the rural and urban people in respect of occupational stress.

(m) $\mathrm{p}$-value $=0.004$, There is a very strong significant relationship.

The people who are feeling occupational stress (stress score $>2.5$ ) have been identified. On the basis of the third part of the questionnaire various health and mental issues are studied among these moderate to higher stressed groups of people and the results are given below:

1. Feeling Nervous: $70 \%$

2. Low in energy: $65 \%$

3. Having blood Pressure: $60 \%$ 
4. Having sugar: $42 \%$

5. Stomach problem: $37 \%$

6. Migraine pain: $38 \%$

7. Depression: $48 \%$

8. Drink alcohol, smoke etc.: $63 \%$

9. Prefer to stay alone: $31 \%$

10. Think about suicide: $18 \%$

11. Crying regularly: $23 \%$

12. Sleeping problem: $54 \%$

So, the most stressed person are facing numerous mental and physical problems.

Few of them confess that when they get their near and dear once then they overcome their stress. Also, the less stressed respondents on an average report that the environment of the work place is good and the colleagues are helpful. Plenty of them are getting positive impact of meditation and yoga therapy to reduce stress.

In our analysis we have seen:

1. Age has significant impact on stress. Generally, the people of age groups 20-30 and 30-40 are feeling more stress than the people of other age groups. They are relatively inexperienced. Lots of pressures, competitions are in the workplace. Salary is sometimes not satisfactory. Some of them are also thinking to change the present job. Maximum people started their martial life from these age groups. So, there may arise financial problems.

2. Occupation itself is a big issue of stress. A child generally growing on with specific dreams on his/her eyes to become a doctor, or engineer or teacher etc. But they are often forced to start their career in some other direction for financial security. This is sometime difficult to adjust. In IT and nongovernment sectors there are more pressure than the government sectors. They also suffer from job security.

3. Occupational place may not be suitable for some people. The surrounding environment may create pressure to the people.

4. Management system plays a significant role to increase or decrease pressure. It has been found that employees under a good management authority feel less pressure than an unorganized management authority.

5. Male and Female are equally stressed.

6. Overtime in occupational place and not spending enough time with family members are significant reason of mental stress.

7. A person who must work after the office at home also is more stressed than who does not work after the office hour. Therefore, the people of IT and nongovernment profession complain more stress than a government employee. Even some people work on their holidays as well.
8. Person who gets a smaller number of holidays feel more stressed. The relaxation time is minimum for them.

9. The people of urban area are busier and not get enough time to relax than the people of rural area. In rural area the environment itself makes people calm. The interactions among the neighbors are good among the rural people. They can share their problems with plenty of neighbors. On the other hand, in urban area individuals have less time to listen other. Also, in urban area there is a competition among the employees. This competition is less in rural area.

10. The people who share thoughts/views are lesser stressed.

11. Income is another issue of stress. Most of the people are not happy with their income. The price of the necessary items is raised day after day, but salary hike is not copping with it for few people.

12. The people who work at night are more stressed than the people work at day shift.

13. Help from colleagues reduces the work pressure and hence the stress.

14. A person, who feels free at the time of working, is less stressed than a person who is not.

15. If anybody gets promotion timely and there is no undue advantage given to promotion of the other by the management then he/she is less stressed.

16. Marital persons are more stressed than single.

17. Transportation is another factor of stress. If the transport system becomes smooth, then employers are less stressed. If the transportation system is not smooth enough then how to go and return from office is a major concern to the people and this may lead to bring stress.

18. Stress causes numerous mental and physical problems. Most of the stressed persons report that they do not sleep well. Even sleeping tablets become useless. Some of them are suffering from head migraine. Some of them confess that take alcohol and smoke regularly to release the pressure. Stomach infection, high blood pressure, sugar, migraine, abnormality are the common symptoms among the stressed people.

\section{CONCLUSION}

The present paper identified different factors that influence stress level at the workplace. Age, occupational type, spending time at workplace, the priority of the individual at his/her workplace, transportation, income, job satisfaction, no break in work etc. are the main causes find for increasing stress level. This work also shows that the stress affects the mental and physical condition of employees in negative way. However, if the colleagues are helpful and the environment of workplace is good then the stress may be reduced. Some appropriate policies may be taken by the management authority and the individuals to reduce the stress level. If the authority 
listens employee's problem and if possible, bring him or her at nearest to their home then stress may also be reduced. Work from home often reduces stress. Fare selection process, allowing vacations whenever a person tired, reduction of transportation cost, counseling time to time, job security, hike of income, acknowledging work, making clear understand about the tasks and responsibility, reduction of working time, proper shift schedules, organizing training programs, appropriate medical surveillance may be included for making policy to reduce occupational stress. Meditation, yoga, regular exercise, music therapy, leading a balance life may be helpful to reduce stress level.

\section{ACKNOWLEDGEMENT}

I would sincerely like to thank University Grant Commission (UGC), India for financial support for the research work (F.PSW-120/15-16 (ERO).

\section{REFERENCES}

[1] Angelo, R.P., \& Chambel, M.J. (2013). An intervention with firefighters to promote psychological occupational health according to the job demands-resources model. Revista De Psicologia Social, 28 (2), 197-210.

[2] Bandyopadhyay, B, \& Sen, D. (2014). Occupational Stress among Women Moulders: A Study in Manual Brick Manufacturing Industry of West Bengal. International Journal of Scientific and Research Publications, 4 (6), 1-7.

[3] Barnett, R. C., \& Brennan, R. T. (1995). The relationship between experiences and psychological distress: A structural equation approach. Journal of Organizational Behavior, 16, 259-276.

[4] Berg, A.M., Hem, E., Lau, B., \& Ekeberg, $\varnothing$. (2006). An exploration of job stress and health in Norwegian police service: a cross sectional study. Journal of Occupational Medicine and Toxiology, Article 26, 1-26.

[5] Bhatia, N., Kishore, J., Anand, T., \& Jiloha R.C. (2010). Occupational stress amongst nurses of two tertiary care hospitals in Delhi. Australas Med Journal, 3, 731- 738.

[6] Bhuin, P.K. (2017). A Study on Work-related Stress among the Teachers and Administrators of Privately Managed Business Schools in West Bengal. Bhatter College Journal of Multidisciplinary Studies, 7 (2), 7-16.

[7] Census report (2011) https://www.censusindia.co.in/states/westbengal

[8] Cooper, C., Sparks, K., Specter, P.E., Miller, K., \& Greyling, M. (2014). Gender differences in occupational stress and strain in facts and theories through different cultural sectors. Stress Medical management, 321-328.

[9] Cohen, J \& Single, L.E. (2001). An examination of the perceived impact of flexible work arrangement on professional opportunities in public accounting. Journal of Business Ethics, 32 (4), 317-319.

[10] Deb, S., Chakroborty, T., Chatterjee, P. \& Srivastava, N. (2008). Job-related stress, causal factors and coping strategies of traffic constables. Journal of the Indian Academy of Applied Psychology, 34 (1), 19-28.

[11] Emsley, D. (2003). Multiple goals and managers' job-related tension and performance. Journal of Managerial Psychology, 18 (4), 345356.

[12] Fisher, A.G. (1933). Production, primary, secondary and tertiary. Econ. Rec, 15 (1), 24-38.

[13] Harshana, P.V.S. (2018). Work related stress: a literature review. Annals of Social, Sciences \& Management studies, Juniper Publishers Inc, 2 (3), 59-65.

[14] Hasan, A. (2014). A study of occupational stress of primary school teachers. Educationia Confab, 3 (4), 11-19.
[15] Jagdish, \& Srivastava, A. K. (1989). Perceived Occupational Stress and mental health: A case study. Indian Journal of Industrial Relations, 24 (4), 444- 452.

[16] Jayashree, R. (2010). Stress management with special reference to public sector bank employees in Chennai. International Journal of Enterprise and Innovation Management Studies, 1 (3), 34-35.

[17] Kakada, P., \& Deshpande, Y.M. (2018). The empirical study of work environment and job stress among teaching faculty. IOSR Journal of Business Management, 20 (1), 29-33.

[18] Kavitha, P. (2012). Role of stress among women employee forming majority workforce at IT sector in Chennai and Coimbatore. SONA-Global Management Review, 6 (3).

[19] Kulkarni, G.K. (2006). Burnout. Indian Journal of Occupational and Environmental Medicine, 10, 3-4.

[20] Lait, J., \& Wallace, J.E. (2002). Stress at work: A study of organizational-professional conflict and unmet expectations. Relations Industrielles, 57 (3), 463-490.

[21] Landsbergis, P.A. (1988). Occupational stress among health care workers: a test of the job demands-control model. Journal of Organizational Behavior, 9 (3), 217-239.

[22] Lazarus, R. S., \& Folkman, S. (1984a). Coping and adaptation. In W. D. Gentry (Ed.), The Hand book of Behavioural Medicine. New York, 282-325.

[23] Olivier, M.A.J. \& Venter, D.J.L. (2003). The extent and causes of stress in Teachers in George region. South African Journal of Education, 23 (3), 186-192.

[24] Manshor, A. T., Fontaine, R. \& Chong, S. C. (2003). Occupational stress among managers: A Malaysian survey. Journal of Managerial Psychology, 18, 622-628.

[25] Manton, A.G. (1990). Job relocation, stress and the family. Journal of Organizational Behavior, 11, 401-406.

[26] Michie, S. (2002). Causes and management of stress at work. Occupational and Environmental Medicine, 59, 67-72.

[27] Mondal, R. \& Mistry, P. (2018). A Study on occupational stress of elementary school teachers in West-Bengal. JETIR, 5 (10), 289293.

[28] Nagra, V., \& Arora, S. (2013). Occupational stress and health among teacher educators. International Journal of Advanced Research in Management and Social Sciences, 2 (8), 1-13.

[29] Nelson, D.L., \& Sutton, C.D. (1990). Chronic work stress and coping: A longitudinal study and suggested new directions. Academy of Management Journal, 33 (4), 859-869.

[30] Orpen, C. (1991). Occupational stress and personal strain: A conceptual model. Management and Labour Studies, 16 (1), 11-21.

[31] Parray, W.M., Kumar, S. \& Awasthi, P. (2016). Stress among teachers: a theoretical examination. The international journal of Psychology. 3 (4). 88-97.

[32] Plaisier, I., de Bruijn, J.G., de Graff, R., Have, M.T., Beekman, A.T., Penninx, B.W. (2007). The contribution of working conditions and social support to the onset of depressive and anxiety disorders among male and female employees. Soc Sci Med, 64 (2), 401-410.

[33] Purakait, S (2016). Impact of occupational stress on quality work life among employees in banking sector: a study in West Bengal region. International Journal of Advanced Research, 4 (7), 12151222.

[34] Rathore, S. \& Ahuja, V. (2015). A study of roll stress among the IT professional in India. International Journal of Human Capital and Information Technology Professionals, 6 (2), 1-13.

[35] Shah, F.A. (2003). Role stress in Indian Industry: A study of banking organizations. Indian Journal of Industrial Relations. Shriram Centre for Industrial Relations and Human Resources, 38 (3), 281-296.

[36] Sharma, A.K.., Khera, S., \& Khandekar, J. (2006). Computer Related Health Problems Among Information Technology Professionals in Delhi. Indian Journal of Community Medicine, 31, 36-38.

[37] Sing, N. \& Katoch, A. (2017). Study of occupational stress of secondary school teachers. International Journal of Advanced Education and Research, 2 (4), 28-33.

[38] Sreelekha, B. \& Rajeswari, H. (2016). Stress among nurses in a tertiary care hospital. The international journal of Indian Psychology, 3 (2), 155-164. 
[39] Stimulus (2006). Enuete Sur le Stress Professional: Rapport complete (3M PDF), Survey on Occupational Stress: Full Report.

[40] Sudhashree, V. P., Rohith, K., \& Shrinivas, K. (2005). Issues and concerns of health among call center employees. Indian Journal of Occupational and Environmental Medicine, 9, 129-132.

[41] Susiarty, A., Suparman, L., Suryatni, M. (2019). The effect of workload and work environment on job stress and its impact on the performance on nurse impatient rooms at Mataram city general hospital. Scientific Research Journal, 7 (6), 32-40.
[42] Upadhyay, B.K. \& Singh, B. (1999). Experience of stress: Differences between college teachers and executives. Psy. Stu. 44 (3), 65-68.

[43] Wastell, D, \& Newman, M. (1993). The behavioural dynamics of information systems managers. Mis quarterly, March.

[44] Weiss, M. (1983). Effects of Work Stress and Social Support. Information Systems Managers, 7, 29-43.

[45] Wilkins, K. \& Beaudet, M.P. (1998). Work Stress and Health. Health Reports, 10 (3), 47-62. 